\title{
RARE EARTH ELEMENTS AS TRACERS FOR PROVENANCING ANCIENT CERAMICS
}

\author{
M. IsAbel Prudêncio(1,2), M. IsAbel Dias $(1,2)$, M. José Trindade ${ }^{(1,2)} \&$ M. Amália \\ SEQUEIRA BRAGA ${ }^{(3)}$
}

\begin{abstract}
Clay analysis plays a crucial role in studies of ancient ceramics, contributing with answers to better understanding resource exploitation strategies, production technologies, and regional and interregional interaction patterns. The vessels are made essentially by clays, the composition of the ceramics reflecting the origin of the clay materials used and conclusions may be inferred concerning the type of raw materials and the establishment of the geographic area of production.

Different geochemical patterns found in clays from different geological contexts, consist on an important basis for the comparison with ceramics since the identification of the clays used for productions can contribute to delimit a potential area of clay resources and thus establishing provenance. This is particularly useful when no archaeological evidence of production exists. REE patterns are very important for the characterization of ceramic productions and their relation with raw materials, as subtle variations between them reflect differences in their relative behaviour in response to the chemical environment, making this group particularly useful in geochemistry studies. So, REE are crucial trace elements to pursue studies of raw materials and provenance establishment and trade routes reconstruction in ancient times.
\end{abstract}

Keywords: Archaeological ceramics; Clays; REE; Provenance.

Resumo

\begin{abstract}
As terras raras como indicadores geoquímicos na proveniência de cerâmica antiga
$\mathrm{O}$ estudo das argilas assume um papel crucial na investigação de cerâmicas antigas, contribuindo para o esclarecimento e melhor compreensão de estratégias de exploração de recursos de matérias-primas, tecnologias de produção e padrões de interacção regional e inter-regional. Os recipientes cerâmicos são essencialmente constituídos por argilas, reflectindo a sua composição a origem dos materiais argilosos usados, podendo ser retiradas conclusões relativamente ao tipo de matérias-primas, bem como ao estabelecimento de áreas geográficas de produção.

Os diversos padrões geoquímicos encontrados nas argilas provenientes de diferentes contextos geológicos, constituem uma importante base para a comparação com as cerâmicas, uma vez que a identificação das argilas usadas em certas produções, pode contribuir para a delimitação da potencial área fonte de argilas, estabelecendo-se assim a sua proveniência. Este facto é particularmente relevante quando não existe evidência arqueológica de produção. Os padrões de terras raras são muito importantes para a caracterização das produções cerâmicas e sua relação com as matérias-primas, uma vez que as variações subtis que apresentam reflectem diferenças no seu comportamento em resposta ao sistema químico que as rodeiam, tornando este grupo particularmente útil em estudos de geoquímica. Deste modo, as terras raras são elementos traço cruciais em estudos de matérias-primas e no estabelecimento de proveniência de cerâmicas, contribuindo para a reconstrução de rotas comerciais em tempos antigos.
\end{abstract}

Palavras-chave: Cerâmicas arqueológicas; Argilas; Terras Raras; Proveniência.

\section{INTRODUCTION}

Ancient ceramics preserve a record of their raw materials within their composition, thus compositional profiles of ceramics and raw materials (clays and temper) are used to trace individual artefacts from their find spot to their origin. The chemical analysis of ceramics and raw materials in support of provenance research has grown rapidly over the past few decades. Compositional data together with classical archaeological approaches has been largely used in solving a broad variety of questions and an overview of these types of studies is well described and summarized in the literature (RICE 1987; CHAPPell 1991; NefF 1992; Velde \& DRUC 1999; Tite 2008). Chemical analysis of ceramics and of raw materials, determining the larger number of chemical elements as possible (especially trace elements),

(1) IST/ITN, Universidade Técnica de Lisboa, EN 10, 2686-953 Sacavém, Portugal, iprudenc@itn.pt

(2) GeoBioTec (FCT), Univ. Aveiro, Campus de Santiago, 3810-193 Aveiro, Portugal

(3) Departamento de Ciências da Terra, Universidade do Minho, Campus de Gualtar, 4710-057 Braga, Portugal 
is particularly useful in provenance studies. In this way, large data sets are generated, which need to be processed by computer with statistical programs. One important thing to not forget is that statistical analysis is only a tool to help us with very large amount of data matrixes (variables and samples) and remember that the results obtained are an approximation of the reality. The attribution of one pot to one particular site or compositional group is based on statistical probabilities. Thus the results obtained by statistical analysis must be checked taking into account geochemical considerations. In some cases, an important step prior to any statistical analysis is normalization of the chemical elements contents. Normalization in archaeological ceramics studies is defined as a procedure to compensate for the influence of natural (geological and ceramic burial time) and anthropogenic (technology of production) processes on the measured variability of the concentration of elements, emphasizing the importance of taking into account geochemical behaviour of the element chosen for normalization. Among conservative elements, scandium appears to be quite appropriate to normalize chemical data (DIAS \& PRUDÊNCIO 2008).

A discussion of pottery must include clay and its origin, composition and properties. Thus, the use of clay resources is very important in deciphering the provenance of a ceramic object, i.e., the geographic area where the object was produced, especially when no archaeological evidence of pottery workshops are found. In the past, the potter was tied to the local/regional resources for his production, and would have adapted local resources to answer specific needs. Sources of clays tended to be those easily available - soils or surface sediments are likely candidates.

\section{The Role of Ree in ArChaeometric STUDIES}

Among trace elements, rare earth elements (REE) can be particularly useful in distinguishing clayey materials resources. The subtle variations in the properties of REE make them sensitive to mineral/melt equilibrium, as well as to weathering conditions after the breakdown of primary minerals and the formation of new mineral phases, sedimentary sorting, and diagenesis (MCLENNAN 1989). These elements have very similar chemical and physical properties, and the dominant oxidation state is the +3 state; there is a small but steady decrease in ionic radius with increasing atomic number; therefore the REE tend to occur in nature as a group. The differences existing among the REE lead to differences in their relative behaviour in response to the chemical environment, making this group particularly useful in geochemistry since they can be a pointer of the genesis processes of the rocks and minerals and subsequent alterations.

The REE are usually divided in light REE (LREE), middle REE (MREE) and heavy REE (HREE). The fractionation between LREE and HREE is measured by the $(\mathrm{La} / \mathrm{Yb})_{\text {ch }}$ ratio, i.e. the ratio between the $\mathrm{La}$ and $\mathrm{Yb}$ concentrations normalized to chondrites. REE occur in a trivalent state in most of the temperature-pressure conditions of the earth, except $\mathrm{Ce}$ and $\mathrm{Eu}$. Under oxidizing conditions, $\mathrm{Ce}^{3+}$ may be oxidized to $\mathrm{Ce}^{4+}$ leading to a decrease in the ionic radius. This reaction occurs on a large scale in the marine environment, associated with the formation of manganese nodules, with a consequent depletion of $\mathrm{Ce}$ in ocean waters. On a smaller scale, this reaction also occurs in superficial environments during weathering (GOUVEIA et al. 1993; PRUDÊNCIO et al. 1993, 1995). Under reducing conditions, europium may exist in the divalent state. Europium is the only element for which a significant proportion of the ions in igneous systems are likely to be present in valences other than $3+$, leading to an anomalous behaviour. This anomalous characteristic of Eu can be expected for many minerals, but is most pronounced for plagioclases, because $\mathrm{Eu}^{2+}$ is similar to $\mathrm{Sr}^{2+}$ and substitutes much more easily for $\mathrm{Ca}$ and $\mathrm{Na}$ in the large feldspar site than does $\mathrm{Eu}^{3+}$. The amount of feldspars (particularly plagioclase) or the fates of Eu after the breakdown of these primary minerals during weathering and sedimentary processes, have an important control on the Eu anomaly of residual or sedimentary clayey materials. Thus $\mathrm{Ce}$ and $\mathrm{Eu}$ anomalies may occur depending on several factors, and may be used as indicators of geological formations (PRUDÊNCIO et al. 1993; MARQUES et al. 2011, 2012; PRUDÊNCIO 2009).

Among the existing analytical methods for chemical contents determination, the instrumental neutron activation analysis (INAA) method has a number of advantages over most other analytical methods when investigating archaeological specimens. INAA is a sensitive, precise and accurate technique for quantitative multi-element analysis. A small amount of sample is required which is an obvious advantage when dealing with cultural heritage materials. The potential of this method as an archaeological tool to establish the provenance of archaeological ceramics was first recognized by Robert Oppenheimer in 1954 (SAYRE \& Dodson 1957; HarbotTle 1976). Since then numerous works have been done using this method. After fifty years of successful NAA applications to archaeology, a special issue of Archaeometry (vol. $49,2007)$ was published with contributions describing the history of several NAA laboratories and case 
studies of archaeological artefacts, including several case studies concerning ceramics provenance (DIAS \& PRUDÊNCIO 2007; HANCOCK et al. 2007; KILIKOGLOU et al. 2007). The application of the INAA method using the Portuguese Research Reactor (RPI) as neutrons source in support of provenance research has been largely used over the past few decades in the IST/ITN, where a large compositional database of ceramics from different chronologies and archaeological sites, as well as of raw materials exists nowadays (CABRAL et al. 1988; DiAs et al. 2002, 2003a, 2003b, 2005a, 2005b, 2009; 2010; PRUDÊNCIO et al. 1989; PRUDÊNCIO et al. 2003, 2006, 2009; TRINDADE et al. 2010a, 2010b; MARQUES et al. 2010).

\section{Using Ree for Provenancing Ancient Ceramics: The CaSe of Roman PotTERY FROM ARCHAEOLOGICAL Sites of NW Iberian Peningula}

Bracara Augusta (Braga, NW Portugal) was a Roman town recognized as a centre of production and distribution of pottery to a wide regional area (MARTINS \& DELGADO 1995, 1989-90a, 1989-90b). Among the shards found in Braga, different types of Roman pottery could be recognized, such as Bracarense, polished fine grey, painted ceramics, late grey ceramics, local amphorae production, non-vitreous red slips ware and several types of common ware. Similar shards have been found in other archaeological sites of the NW Iberian Peninsula region, such as Aquis Querquennis (Galiza, Spain), which together with the absence of kilns near Braga, question the production centre's location. The chemical characterization of the pastes of different types of ceramics found in Bracara Augusta was done in an attempt to confirm the morphological classification by macroscopic observation of the pastes, with particular emphasis in the REE patterns. While provenance studies may be able to identify the kinds of clay material used in a particular type of pottery, they do not provide information on the cultural or socioeconomic context, such as the location of workshops, which depends on the finding of kilns, deposits of raw materials, wasters, etc. at a site. The approach adopted for the establishment of the existence of ceramic production in Bracara Augusta (town and vicinities areas) has been a combination of the abundance of the types of potteries (forms and paste types) and comparisons of the ceramic composition with clay resources available in the area (PRUDÊNCIO et al. 2006).

The inventories of the regional clay materials between the city of Braga and the shoreline and their mineralogical characterization were previously re- ported (SEQueIRA Braga 1988; SEQUeIRA Braga et al. 2002): (a) near Braga - (i) clays derived by weathering of schists (Espinheira and Bustelo); (ii) sedimentary deposits of small temporary basins (Ucha and Quebrosas); (iii) clays derived by weathering of the Braga granite; (iv) Prado sediments; and (b) near the coast - (v) residual kaolin; and (vi) sedimentary kaolin.

Chemical analyses of shards (paste) and clay materials were performed by means of instrumental neutron activation analysis (INAA). Our procedure for INAA has been fully described elsewhere (PRUDÊNCIO et al. 1986, 1988), and will only be summarised here: the analysis were performed using a $\gamma$-ray spectrometer consisting of a $150 \mathrm{~cm}^{3}$ coaxial Ge detector and a low energy photon detector (LEPD), connected through Canberra 2020 amplifiers to Accuspec B (Canberra) multichannel analyser were used. This system had a FWHM of $1.9 \mathrm{keV}$ at $1.33 \mathrm{MeV}$ (coaxial Ge detector), of 300 $\mathrm{eV}$ at $5.9 \mathrm{keV}$ and of $550 \mathrm{eV}$ at $122 \mathrm{keV}$ (LEPD). The irradiations were carried out in the core grid of the Portuguese Research Reactor (Sacavém) at a flux of $4.4 \times 10^{12} \mathrm{n} \times \mathrm{cm}^{-2} \mathrm{~s}^{-1}$ for seven hours. This method allowed obtaining the concentrations of $\mathrm{La}, \mathrm{Ce}, \mathrm{Nd}$, $\mathrm{Sm}, \mathrm{Eu}, \mathrm{Tb}, \mathrm{Yb}$, and $\mathrm{Lu}$.

The first geochemical approach was done to the two main typological groups of ceramics pastes found in large amounts in Braga - Bracarense and common ware, in order to characterize in a compositional point of view, by using REE, trying to differentiate, or not, these two productions. The REE were normalized to chondrites (HASKIN 1971) and the patterns obtained well characterize and differentiate those two types of paste (Fig. 1). All ceramics have LREE/HREE fractionating, a significant Eu anomaly, and no important Ce anomaly was detected. Bracarense ceramics from Bracara Augusta (BA) and Aquis Querquenis (AQ) have similar Eu anomaly $(\mathrm{BA}=0.41 ; \mathrm{AQ}=0.40)$ and REE fractionating degree $\left[\mathrm{BA}(\mathrm{La} / \mathrm{Yb})_{\mathrm{ch}}=6.16\right.$; $\mathrm{AQ}$ $\left.(\mathrm{La} / \mathrm{Yb})_{\mathrm{ch}}=5.96\right]$. Common ware $(\mathrm{CW})$ have a similar Eu anomaly $(\mathrm{CW}=0.44)$ when comparing with Bracarense ceramics, but a higher REE fractionating $\left[\mathrm{CW}(\mathrm{La} / \mathrm{Yb})_{\mathrm{ch}}=11.3\right]$. These differences point to the use of different raw materials.

Concerning the clay deposits located near the coast, the sedimentary kaolin (Sk) is more concentrated in REE and the MREE and HREE contents vary more than the LREE, particularly $\mathrm{La}$ and $\mathrm{Ce}$ (Fig. 2) than the residual kaolin (Rk). In average the Eu anomaly of the sedimentary kaolin $\left(\mathrm{Eu} / \mathrm{Eu}^{*}=0.38\right)$ is more pronounced than the residual kaolin $(\mathrm{Eu} /$ $\mathrm{Eu}^{*}=0.52$ ), and the fractionating degree is lower and less variable [Sk $\left.(\mathrm{La} / \mathrm{Yb})_{\mathrm{ch}}=7.9 ; \mathrm{Rk}(\mathrm{La} / \mathrm{Yb})_{\mathrm{ch}}=8.5\right]$.

Concerning the clay deposits located near Braga 

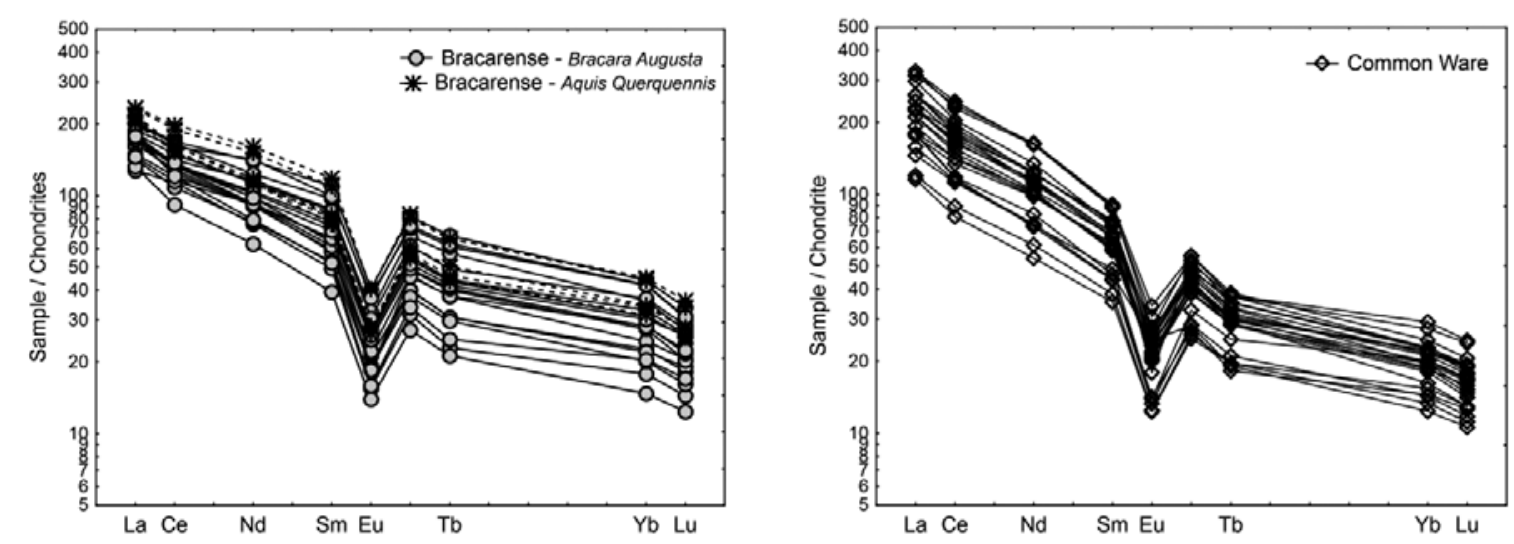

Fig. 1. REE patterns of the Bracarense and common ware ceramic bodies.

Fig. 1. Padrões de Terras Raras das pastas de cerâmicas Bracarense e comum.
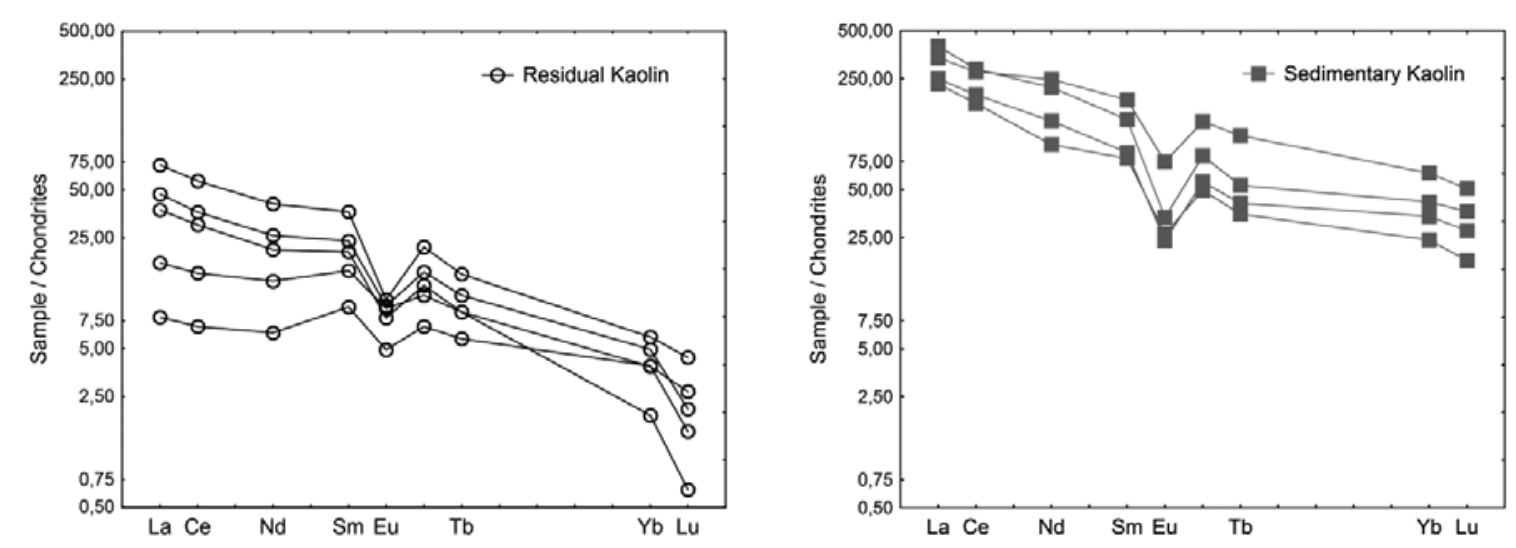

Fig. 2. REE patterns of residual and sedimentary kaolin deposits located near the coast.

Fig. 2. Padrões de Terras Raras de depósitos de caulinos residuais e sedimentares localizados na costa.

(Fig. 3), the weathered derived materials have substantial differences: the granites (WG) have a higher $\mathrm{LREE} / \mathrm{HREE}$ ratio $\left[\mathrm{WG}(\mathrm{La} / \mathrm{Yb})_{\mathrm{ch}}=19.8\right]$ relatively to schists (WS) [WS $\left.(\mathrm{La} / \mathrm{Yb})_{\mathrm{ch}}=7.25\right]$, as well as higher negative Eu anomaly [WG $\left(\mathrm{Eu} / \mathrm{Eu}^{*}\right)=0.41$; WS $(\mathrm{Eu} /$ $\left.\mathrm{Eu}^{*}\right)=0.53$ ]. Regarding the sedimentary basin deposits, the sediments of the Prado basin (PS) have higher REE contents, when compared with the small basins of Ucha and Quebrosas (UQ) and higher Eu anomaly [PS $\left(\mathrm{Eu} / \mathrm{Eu}^{*}\right)=0.45$; UQ $\left(\mathrm{Eu} / \mathrm{Eu}^{*}\right)=0.52$ ]; the REE fractionating is very similar in both deposits [PS $(\mathrm{La} / \mathrm{Yb})_{\mathrm{ch}}=11.7$; UQ $\left.(\mathrm{La} / \mathrm{Yb})_{\mathrm{ch}}=11.1\right]$.

The REE patterns of both sedimentary basin deposits and weathered materials suggest that the Prado sediments had a more important contribution of granites as source materials than of schists, especially due to higher REE content and similar Eu anomaly, which is usually a sign of inherited characteristics. On the other hand, the sediments from the small basins of Ucha and Quebrosas point to a composition more similar to the weathered schist (PRUDÊNCIO et al. 2006; PRUDÊNCIO 2009).

The chemical characteristics of clay resources and of the two types of ceramics studied (Bracarense and common ware) are a useful tool to attribute relationships between and within them, thus providing provenance insights. The comparison of REE behaviour showed that the most probable raw materials used to obtain the common ware paste, occurs near Braga, namely the clays of the Prado sedimentary basin, especially considering the similarity of the $\mathrm{Eu}$ anomaly $(\mathrm{CW}=0.44$; $\mathrm{PS}=0.45)$ and of the $\mathrm{REE}$ fractionating $(\mathrm{La} / \mathrm{Yb})_{\mathrm{ch}}$ ratio $(\mathrm{CW}=11.3$; $\mathrm{PS}=11.7)$ of both $\mathrm{CW}$ and PS. On the other hand the Bracarense ceramics have REE patterns similar to those found in the sedimentary kaolins, presenting comparable 


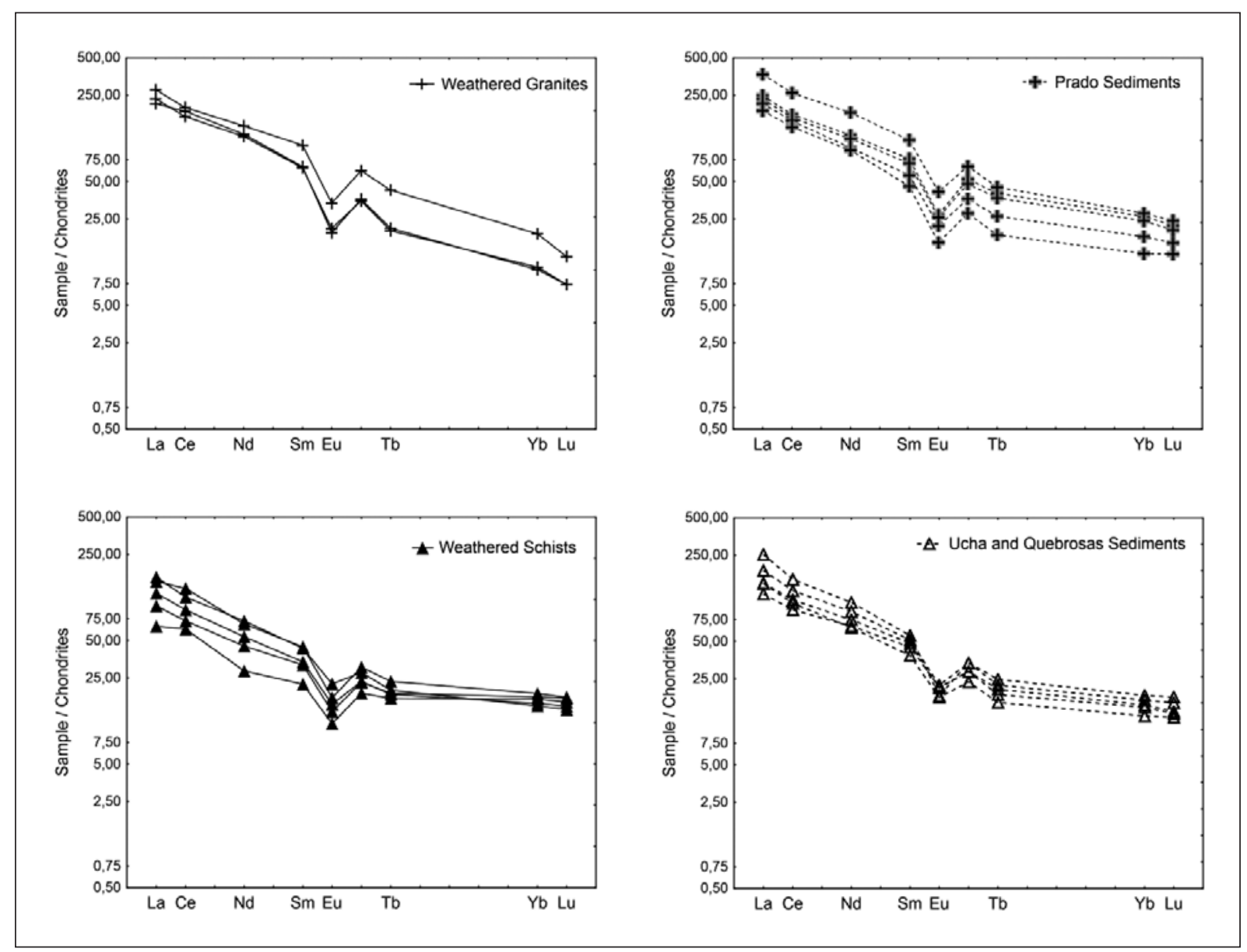

Fig. 3. REE patterns of clays located near Braga of: weathered granite; weathered schists; sediments of the Prado basin; and sediments belonging to small sedimentary basins (Ucha and Quebrosas).

Fig. 3. Padrões de Terras Raras de argilas localizadas na região de Braga provenientes de: granitos alterados; xistos alterados; sedimentos da bacia do Prado; e sedimentos de pequenas bacias sedimentares (Ucha e Quebrosas).

Eu anomaly $(\mathrm{BA}+\mathrm{AQ}=0.41 ; \mathrm{Sk}=0.38)$ and $(\mathrm{La} / \mathrm{Yb})_{\mathrm{ch}}$ ratios $(\mathrm{BA}+\mathrm{AQ}=6.1 ; \mathrm{Sk}=7.9)$.

In this way, two main types of pastes appear to exist in shards of different typologies found in large amounts in Bracara Augusta and vicinity (the "Bracarense paste" and the "common ware paste"), pointing to local/regional productions with the use of two main types of local/regional raw materials (sedimentary kaolins and Prado sediments), clearly emphasized by REE patterns. The absence of archaeological evidence of ceramic production justifies the chemical clay tracing to establish provenance and confirm local/regional productions.

\section{FINAL REMARKS}

Compositional analysis of archaeological ceramics and raw materials, together with classical archaeological methods are a powerful approach to solve questions dealing with provenance, technology and use of such artefacts in ancient times. Clay analysis plays a crucial role in studies of ancient ceramics, contributing with answers to better understanding resource exploitation strategies, production technologies, and regional and interregional interaction patterns. The vessels are made essentially by clays, the composition of the ceramics reflecting the origin of the clay materials used and conclusions may be inferred concerning the type of raw materials and the establishment of the geographic area of production.

Considering trace elements, the REE are a group particularly useful in geochemistry, since they can be a pointer of the genesis processes and subsequent alterations, which enables to better fingerprint clays, as well as ceramic pastes, contributing to the correlation with their potential raw materials. In this way, REE may have a special role in ancient ceramics provenancing and thus differentiating local productions from imports, a usual relevant question of cultural heritage researchers. 


\section{REFERENCES}

CAbral, J.M.P.; PrudÊNCIO, M.I.; Gouveia, M.A.; Morais ARNAUD, J.E. 1988. Chemical and mineralogical characterization of Pre-Beaker and Beaker pottery from Ferreira do Alentejo (Beja, Portugal). In R.M. FARQuHAR, R.G.V. HANCOCK \& L.A. PAVlish (ed.), Proceedings of the 26th International Archaeometry Symposium. Archaeometry Laboratory, University of Toronto: 172-178.

CHAPPELL, J. 1991. The potter's complete book of clay and glazes. NY: Watson-Guphill Publications.

DIAS, M.I. \& PRUDÊNCIO, M.I. 2007. Neutron activation analysis of archaeological materials: an overview of the ITN NAA laboratory. Portugal. Archaeometry, 49: 383-393.

DiAS, M.I. \& PRUDÊNCIO, M.I. 2008. On the importance of using Sc to normalize geochemical data previous to multivariate analyses applied to archaeometric pottery studies. Microchemical Journal, 88: 136-141.

Dias, M.I.; Prudêncio, M.I.; VAlera, A.C.; Sequeira Braga, M.A. \& Gouveia, M.A. 2002. Provenance and Technology of Pre-Historic Pottery from Fornos de Algodres (Portugal): The Fraga da Pena archaeological site. British Archaeological Reports, International Series, 1011: 253-264.

Dias, M.I.; Prudêncio, M.I. \& Gouveia, M.A. 2003a. Geochemical study of clay materials in Fornos de Algodres region (Central Portugal) in an archaeometric view. In E. Dominguez, G. Mas \& F. Cravero (eds.), A Clay Odissey. Amsterdam, The Netherlands: Elsevier Science: 65-70.

Dias, M.I.; PrudÊnCIO, M.I. \& Rocha F. 2003b. Amphorae Production at Occidental Lusitania: Identification of Raw Material and Production. In J.L. PÉREZ-Rodríguez (ed.), Applied Study of Cultural Heritage and Clays. Madrid: CSIC: 187-200.

Dias, M.I.; Valera, A.C. \& PrudênCiO, M.I. 2005a. Pottery production technology through out the 3rd millennium B.C. on a local settlement network in Fornos de Algodres, central Portugal. In M.I. PrudênCiO, M.I. Dias \& J.C. WAERENBorgh (eds.), Trabalhos de Arqueologia, Série Monográfica, 42: 41-50.

Dias, M.I.; PrudÊnCiO, M.I.; VAlera, A.C.; LAGo, M. \& GoUVEIA, M.A. 2005b. Composition, Technology and functional features of Chalcolhitic pottery from Perdigões, Reguengos de Monsaraz (Portugal). Geoarchaeological and Bioarchaeological Studies, 3: 161-164.

Dias, M.I.; Viegas, C.; Gouveia, M.A.; Marques, R.; Franco, D. \& PRUDÊNCIO, M.I. 2009. Geochemical fingerprinting of Roman pottery production from Manta Rota kilns (Southern Portugal). In K.T. Biró, V. SZILÁGYI \& A. Kreiter (eds.), Vessels inside and outside, EMAC'07. Budapest, Hungary: Published by the Hungarian National Museum: 83-90.

Dias, M.I.; PrudÊnCIO, M.I.; Gouveia, M.A.; Trindade, M.J.; Marques, R.; Franco, D.; Raposo, J.; Fabião, C.S. \& Guerra, A. 2010. Chemical tracers of Lusitanian amphorae kilns from the Tagus estuary (Portugal). Journal of Archaeological Science, 37: 784-798.

Gouveia, M.A.; Prudêncio, M.I.; Figueiredo, M.O.; Pereira, L.C.J.; Waerenborgh, J.C.; Morgado, I.; PenA, T. \& LoPES, A. 1993. Behaviour of REE and other trace and major elements during weathering of granitic rocks, Évora, Portugal. Chemical Geology, 107: 293-298.

Hancock, R.G.V.; PAvlish, L.A. \& Aufreiter, S. 2007. Archaeometry at slowpoke-toronto. Archaeometry, 49: 229-243.

Harbottle, G. 1976. Activation Analysis in Archaeology. In G.WA. Newton (ed.), Radiochemistry 3. London: The Chemical Society: 33-72.
Haskin, L.A.; HelmKe, P.A.; PAster, T.P. \& Allen, R.O. 1971. Rare earths in meteoritic, terrestrial, and lunar matter. In A. BRUnfelt \& E. Steinnes (eds.), Activation Analysis in Geochemistry and Cosmochemistry, Proc. NATO Conf. on Activation Analysis in Geochemistry. Oslo: Universitetsforlaget: 201-218.

Kilikoglou, V.; Grimanis, A.P.; Tsolakidou, A.; Hein, A.; Malamidou, D. \& TSIRTSONI, Z. 2007. Neutron activation patterning of archaeological materials at the national center for scientific research "Demokritos": the case of black-onred neolithic pottery from macedonia, greece. Archaeometry, 49: 301-319.

Marques, R.; Jorge, A.; Franco, D.; Dias, M.I. \& Prudêncio, M.I. 2010. Clay resources in Nelas region (Beira Alta), Portugal. A contribution for the characterization of potential raw materials for prehistoric ceramic production. Clay Minerals, 45: 353-370.

Marques, R.; Dias, M.I.; PrudênCIO, M.I. \& RochA, F. 2011. Upper cretaceous clayey levels from western portugal (Aveiro and Taveiro regions): clay mineral and trace-element distribution. Clays and Clay Minerals, 59: 315-327.

Marques, R.; Prudêncio, M.I.; Rocha, F.; Pinto, M.; Silva, M. \& SILVA, E.F. 2012. REE and other trace and major elements in the topsoil layer of Santiago Island, Cape Verde. Journal of African Earth Sciences, 64: 20-33.

Martins, M. \& Delgado, M. 1989-90a. As necrópoles de Bracara Augusta: os achados arqueológicos. Cadernos de Arqueologia, II, 6/7: 41-186.

Martins, M. \& Delgado, M. 1989-90b. História e Arqueologia de uma cidade em devir: Bracara Augusta. Cadernos de Arqueologia, II, 6/7: 11-38.

Martins, M. \& Delgado, M. 1995. Bracara Augusta: Uma cidade na periferia do império. Actas do Colóquio Internacional de Arqueologia "Los finisterres Atlânticos en la Antiguedad (época preromana y romana)": 121-128.

MCLENNAN, S.M. 1989. Rare earth elements in sedimentary rocks; influence of provenance and sedimentary processes. Reviews in Mineralogy and Geochemistry, 21: 169-200.

NEFF, H. 1992. Chemical characterization of ceramic pastes in archaeology. Monographs in World Archaeology 7. Madison, Wisconsin: Prehistory Press.

PRUDÊNCIO, M.I. 2009. Ceramic in Ancient Societies: a role for nuclear methods of analysis. In A.N. KOSKINEN (ed.), $\mathrm{Nu}$ clear Chemistry: New Research. New York: Nova Science Publishers, Inc.: 51-81.

PRudÊNCIO, M.I.; GouveIA, M.A. \& CABRAL, J.M.P. 1986. Instrumental neutron activation analysis of two French geochemical reference samples - Basalt BR and Biotite Mica-Fe. Geostandards Newsletter, X, 1: 29-31.

PRudÊNCIO, M.I.; GOUVEIA, M.A. \& CABRAL, J.M.P. 1988. Instrumental neutron activation analysis of NBS-97a Flint Clay and NBS-98a Plastic Clay reference samples with a view to their use as standards for archaeological studies and clay studies. Journal of Trace and Microprobe Techniques, 6: 103-111.

PrudÊnCIO, M.I.; Figueiredo, M.O. \& CABRAL, J.M.P. 1989. Rare earth distribution and its correlation with clay mineralogy in the clay-sized fraction of cretacic and pliocenic sediments (central Portugal). Clay Minerals, 24: 67-74.

PrudÊNCIO, M.I.; BragA, M.A.S. \& GouveIA, M.A. 1993. REE mobilization fractionation and precipitation during weathering of basalts. Chemical Geology, 107: 251-254.

Prudêncio, M.I.; Gouveia, M.A. \& Sequeira Braga, M.A. 1995. REE distribution in actual and ancient surface environments of basaltic rocks (central Portugal). Clay Minerals, 30: 239-248. 
PrudênCIO, M.I.; Dias, M.I.; Raposo, J.; Gouveia, M.A.; FABião, C.; Guerra, A.; Bugalhão, J.; Duarte, A.L. \& SABRosA, A. 2003. Chemical characterisation of amphorae from the Tagus and Sado estuaries production centres (Portugal). In S. Di Pierro, V. Serneels \& M. Maggetti (eds.), Ceramic in the Society: 245-253.

PrudênCIO, M.I.; Oliveira, F.; Dias, M.I.; SEqueira Braga, M.A.; Delgado, M. \& MARTINS, M. 2006. Raw materials identification used for the manufacture of Roman "Bracarense" ceramics from NW Iberian Peninsula. Clays and Clay Minerals, 54: 638-649.

Prudêncio, M.I.; Dias, M.I.; Gouveia, M.A.; Marques, R.; Franco, D. \& TRINDADE, M.J. 2009. Geochemical signatures of Roman amphorae produced in the Sado River estuary, Lusitania (Western Portugal). Journal of Archeological Science, 36: 873-883.

RICE, P.M. 1987. Pottery Analysis, A source book. Chicago: The University of Chicago Press.

SAYRE, E.V. \& Dodson, R.W. 1957. Neutron-activation study of mediterranean potsherds. American Journal of Archaeology, 61: $35-41$.
Sequeira Braga, M.A. 1988. Arenas e depósitos associados da bacia de drenagem do rio Cávado (Portugal) e contribuição para o estudo da arenização. Tese de Doutoramento, Universidade do Minho, Braga.

Sequeira Braga, M.A.; Paquet, H. \& Begonha, A. 2002. Weathering of granites in a temperate climate (NW Portugal): granitic saprolites and arenization. Catena, 49: 41-56.

TITE, M.S. 2008. Ceramic production, provenance and use: a review. Archaeometry, 50: 216-231

Trindade, M.J.; Rocha, F. \& Dias, M.I. 2010a. Geochemistry and mineralogy of clays from the Algarve Basin, Portugal: a multivariate approach to palaeoenvironmental investigations. Current Analytical Chemistry, 6: 43-52.

Trindade, M.J.; Dias, M.I.; Coroado, J. \& Rocha, F. 2010 b. Firing tests on clay-rich raw materials from the Algarve Basin (South Portugal): Study of the mineral transformations with temperature. Clays and Clay Minerals, 58: 188-204.

Velde, B. \& DRUC, I.C. 1999. Archaeological Ceramic, Materials, Origin and Utilization. Berlin, Heidelberg: Springer-Verlag. 